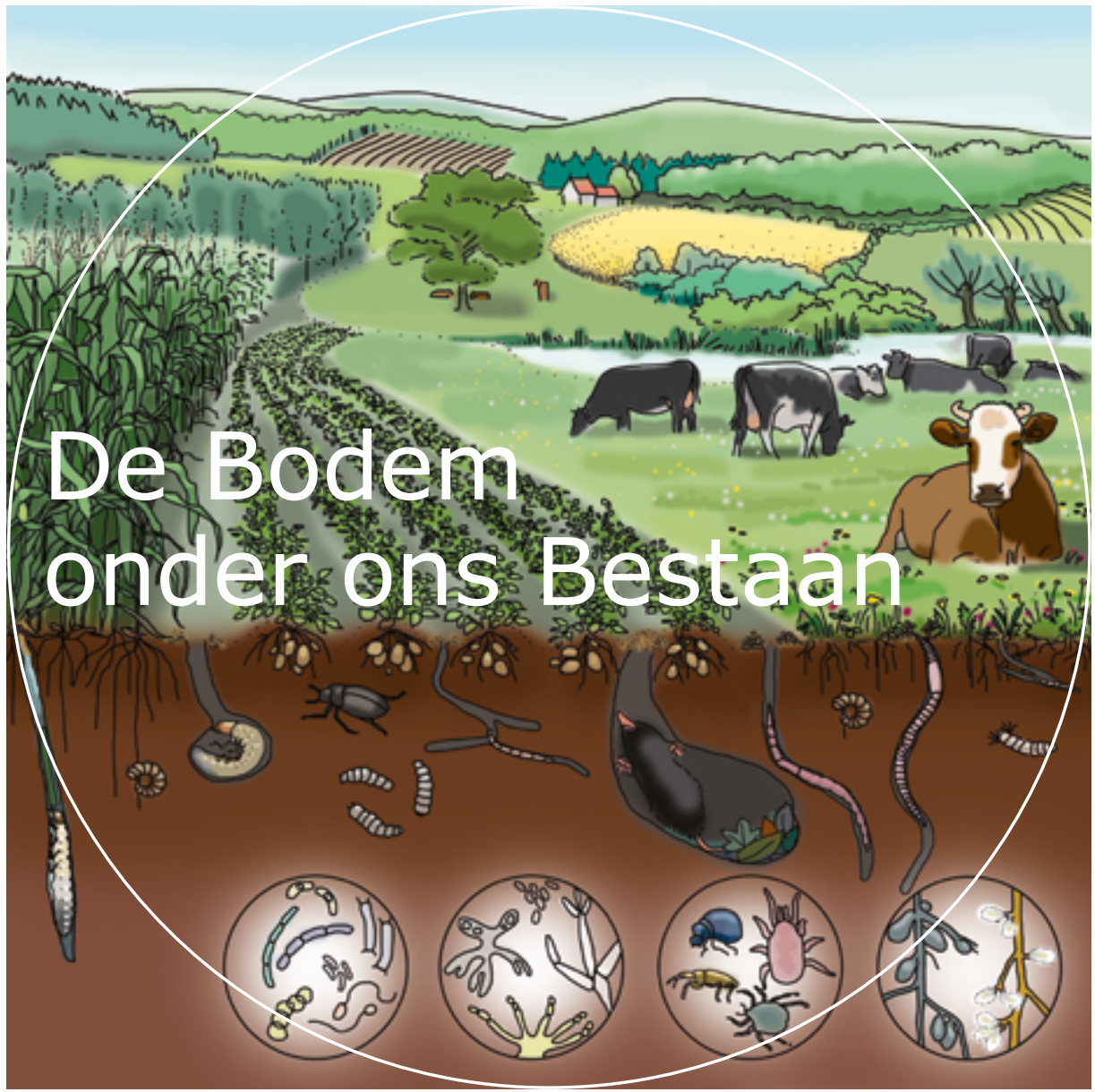

Prof.dr. Lijbert Brussaard

Rede bij het afscheid als hoogleraar in Bodembiologie en Biologische Bodemkwaliteit aan Wageningen University op 6 oktober 2016 



\section{De Bodem onder ons Bestaan}

\section{Prof. dr. Lijbert Brussaard}

Rede bij het afscheid als hoogleraar in de Bodembiologie en Biologische Bodemkwaliteit aan Wageningen University op 6 oktober 2016 
Omslagillustratie: Fingerprint ISBN 978-94-6343-008-1 DOI http://dx.doi.org/10.18174/396108 


\section{De Bodem onder ons Bestaan}

Meneer de rector, dames en heren,

De rector heeft $\mathrm{u}$ al welkom geheten, maar ik wil daar graag aan toevoegen dat ik het erg op prijs stel dat $\mathrm{u}$ aanwezig bent bij mijn afscheidsrede, die ik de titel heb gegeven 'De Bodem onder ons Bestaan'.

Mijn betoog is opgebouwd uit drie delen. Om te beginnen zal ik iets over mijn vakgebied zeggen en dat doe ik in een maatschappelijke context. Daarna zal ik iets zeggen over het onderzoek van mijn leerstoelgroep en daarin zal ik ook de mensen betrekken met wie ik de laatste tijd heb gewerkt. Dat overziende geef ik vervolgens een beschouwing over de waarde(n) van de wetenschap.

\section{Bodembiologie in een maatschappelijke context}

Het jaar 2015, vorig jaar dus, was het 'Internationale Jaar van de Bodem', uitgeroepen door de Verenigde Naties. De VN noemden in dat kader als eerste het belang van de bodem voor de voedselzekerheid. Maar de context was veel breder, namelijk die van de Duurzame Ontwikkelingsdoelen van de VN. Figuur 1 (zie pagina 4) toont dat op een manier die de centrale bijdrage laat zien van bodem en bodemwetenschap in het bereiken van de Duurzame Ontwikkelingsdoelen.

Die bijdrage wordt zeer sterk beïnvloed door de landbouw. Dat geldt niet alleen voor landgebruik, voedselzekerheid en gezondheid, maar ook voor waterbeschikbaarheid, klimaatverandering en behoud van biodiversiteit, simpelweg doordat de landbouw een groot deel van het landoppervlak in beslag neemt: in Nederland twee-derde van het land. Duurzaam bodembeheer vereist in de praktijk dan ook vooral duurzame landbouw.

Duurzame landbouw gaat niet alleen over meer voedselproductie voor een groeiende wereldbevolking, maar ook over maatschappelijke aanvaarding van de manier waaróp we ons voedsel produceren. In lijn daarmee verschuift de focus in het landbouwbeleid van voldoende en veilige producten naar maatschappelijk aanvaardbare productiewijzen. Landbouwbeleid evolueert daarmee in rap tempo in de richting van voedselbeleid, waarin 'voedselketens' meer en meer als onderdeel worden gezien van 'voedselsystemen'. Dat houdt in dat de samenhang en 


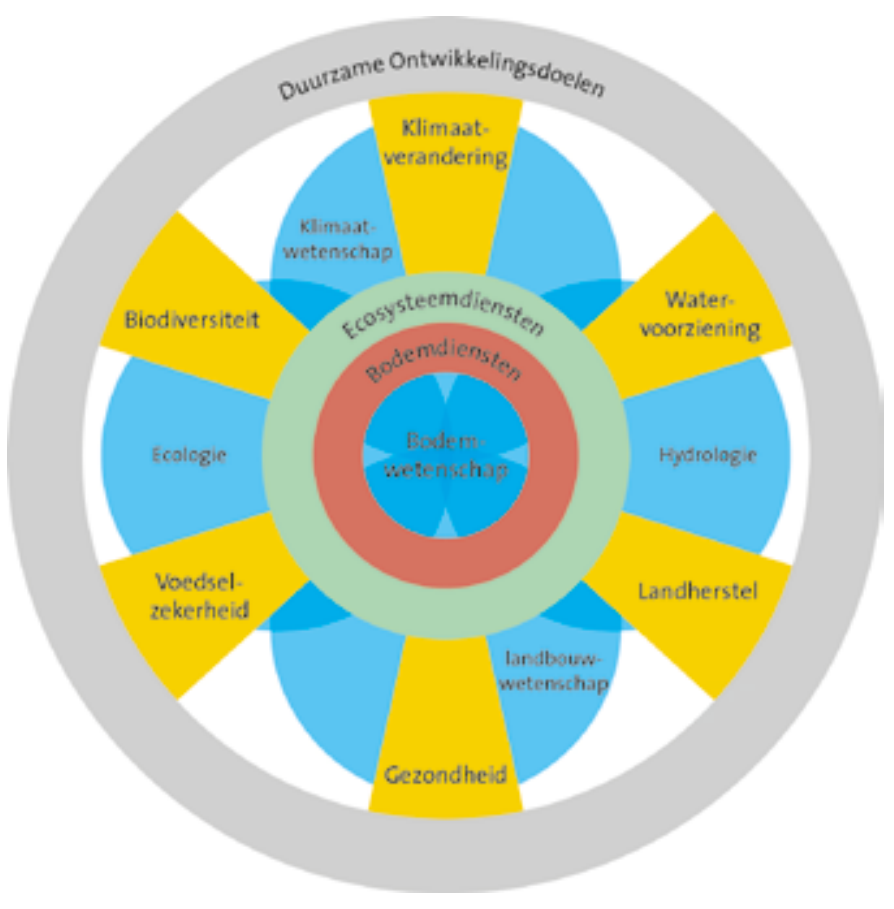

Figuur 1. De (bodem)wetenschap in relatie tot zes thema's van wereldbelang, elk verwijzend naar een of meer van de Duurzame Ontwikkelingsdoelen van de Verenigde Naties (http://www.unric.org/nl/ sdg-in-nederlands): voedselzekerheid, gezondheid, landherstel, watervoorziening, klimaatverandering en biodiversiteit. Naar Keesstra et al. (27).

machtsverhoudingen tussen de spelers op het gebied van productie, verwerking, distributie, groothandel en consumptie van voedsel mede bepaald worden door de waarden in de samenleving ten aanzien van gezondheid, dierenwelzijn, klimaat, milieu en natuur.

Op welke wijze kan nu bodemkennis en de toepassing daarvan tot haar recht komen in het nastreven van de Duurzame Ontwikkelingsdoelen en in het krachtenveld van voedselsystemen? Dat kan op twee manieren: door 'de boer op' te gaan en onze kennis aan te bieden, of door ons te laten betrekken bij maatschappelijke activiteiten die om (ontwikkeling van) bodemkennis vragen. Dat laatste is wel zo inspirerend, omdat het belang van bodemkennis al wordt onderkend op het moment dat je gevraagd wordt om mee te doen. Mijn ervaring is dat dat het beste werkt in de maatschappelijk context van een streek, omdat op streekniveau alle spelers geworteld zijn in concrete praktijken. Ik zal u één voorbeeld geven, dat ik ontleen aan de Hoeksche Waard. Degenen onder $\mathrm{u}$ die weten dat ik daar geboren ben, denken nu natuurlijk 'dat kan geen toeval zijn'. Maar mijn medewerkers en ik zijn lang niet de 
enige Wageningers die in de Hoeksche Waard actief zijn. Dat komt doordat maatschappelijke organisaties aldaar zelf de weg naar ons heel goed weten te vinden en met die organisaties overleggen we als Wageningers soms gezamenlijk in wat wel genoemd wordt een community of scientific practice. Omdat, zoals gezegd, duurzaam bodembeheer vooral duurzame landbouw betekent, is het interessant om uit een recent opgenomen video te vernemen wat de boeren in de Hoeksche Waard daaronder verstaan: http://www.wur.nl/nl/activiteit/Afscheidssymposium-enAfscheidsrede-Prof.-dr.-Lijbert-Brussaard.htm

Het begrip organische stof komt regelmatig voor in deze video. Waar gaat het dan eigenlijk om? Gewasresten die achterblijven op het veld en in de bodem, worden afgebroken door bodemorganismen; het grootste deel verdwijnt binnen een jaar. Dat wil zeggen dat ze dan zijn omgezet in $\mathrm{CO}_{2^{\prime}}$ dat de lucht in gaat, en water plus moleculen die als plantenvoedende stoffen weer kunnen worden opgenomen door het volgende gewas. Een ander deel van de gewasresten blijft langere tijd in de bodem aanwezig als bodemorganische stof (humus), die daarnaast ook nieuw gevormd wordt door diezelfde bodemorganismen (figuur 2).

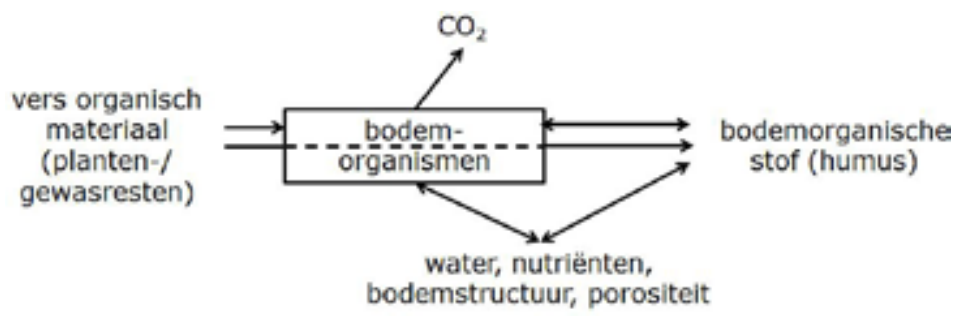

Figuur 2. De centrale rol van bodemorganismen in de dynamiek van bodemorganische stof en de daarmee samenhangende bodemeigenschappen.

De bodemorganische stof heeft belangrijke eigenschappen, zoals het vasthouden en weer afgeven van plantenvoedende stoffen en water en het in stand houden van bodemstructuur en porositeit. De bodemorganismen zelf profiteren daarvan en dragen er op hun beurt ook aan bij. Omdat bodemorganische stof zo'n belangrijke rol speelt, is het op peil houden daarvan een wezenlijk onderdeel van duurzaam bodembeheer. De bodemorganische stof bestaat ruwweg voor de helft uit koolstof. Als we vergelijken hoeveel koolstof er jaarlijks de bodem in- en uitgaat, dan hebben we de koolstofbalans in handen. In de akkerbouw is de balans overwegend neutraal (geel in figuur 3 links) tot achteruitgaand (oranje en rood in dezelfde figuur). Bij grasland is de balans neutraal of positief (niet afgebeeld). 

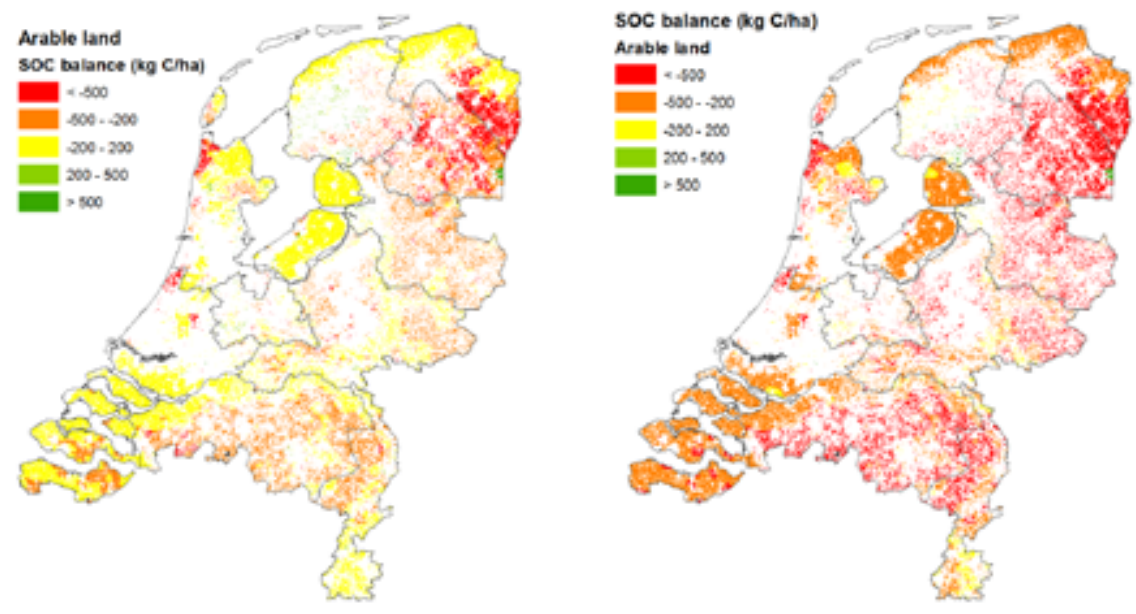

Figuur 3. Berekende bodemorganische koolstofbalans ( $k g \mathrm{C}$ per ha per jaar) voor akkerland in Nederland. Links: huidige situatie. Rechts: effecten van $2^{\circ}$ temperatuurstijging. De koolstofbalans is berekend op basis van de toevoer van organisch materiaal uit gewasresten en mest en de afbraak van bodemorganische stof in de laag $0-25 \mathrm{~cm}$ in het eerste jaar na toediening. Het temperatuureffect is alleen verrekend voor de afbraak; effecten op de productie van gewas(resten) zijn niet verrekend. Bron: Conijn $\mathcal{E}$ Lesschen (22).

$\mathrm{Nu}$ denkt $\mathrm{u}$ misschien dat het in Nederland wel meevalt met de afname van het organische stofgehalte, omdat die beperkt gebleven is tot specifieke teelten, voornamelijk op arme zandgronden, zie de oranje en rode vlakjes in figuur 3 links. Op grasland lijkt er helemaal geen probleem te zijn. Dat komt vooral doordat we al jaren een mestoverschot hebben. Maar die mest is voor een groot deel het resultaat van grootschalige import van veevoer uit het buitenland; is dat duurzaam? En de toepassing van die mest stuit ook nog eens op de beperkingen van de fosfaatwetgeving: niet duurzaam dus. Het probleem van een dalend organische stofgehalte van de bodem zal dus weldra ook in Nederland duidelijk zichtbaar worden en des te sneller naarmate de klimaatverandering doorzet. Dat is te zien in figuur 3 rechts, waarin modelmatig het effect van twee graden temperatuurverhoging is uitgerekend. Zoals u ziet, is nu bijna het gehele akkerbouwgebied oranje of rood. Gezien de verschillende functies die organische stof in de bodem heeft, is het onmogelijk om één algemeen geldend ideaal gehalte organische stof te definiëren. Eén ding is wel duidelijk: het structureel teruglopen van het organische stofgehalte leidt tot afname van álle functies die het heeft. 
Over wat duurzaam bodembeheer betekent voor de akkerbouwers in de Hoeksche Waard hebben zij een helder verhaal. Het bodemleven functioneert het best als de bodem niet of niet-kerend wordt bewerkt, zo min mogelijk en zo licht mogelijk wordt bereden, en niet uitdroogt of onder water komt te staan. Als dat op orde is, is de logische vervolgvraag aan de bodembiologen: als we het bodemleven willen stimuleren om zoveel mogelijk over te nemen van wat we nu doen door menselijk ingrijpen, namelijk grondbewerking, afvoeren van water bij overlast en vasthouden van water bij tekort, hoe moeten we ons organische stofmanagement dan aanpassen?

Voor ik daarop doorga, wil ik deze vraag verbreden. Bij de klimaatonderhandelingen vorig jaar in Parijs hebben de Fransen ingezet op een structurele verhoging van het organische stofgehalte van de bodem in de bovenste $40 \mathrm{~cm}$ met $4 \%$ o per jaar wereldwijd. Dat lijkt heel weinig, maar daarmee kan het broeikaseffect dat leidt tot de opwarming van de aarde volgens hun berekening op den duur teniet worden gedaan. Boer Leen Jan Reedijk heeft, zoals $u$ in de video kon zien, op zijn bedrijf in de Hoeksche Waard het organische stofgehalte van 2 tot $3.3 \%$ verhoogd in een periode van 20 jaar, dat is over een diepte van $40 \mathrm{~cm}$ gemiddeld $\mathrm{zo}^{\prime} \mathrm{n} 1.5 \%$ per jaar. Hij werkt op een grond die daarvoor in principe geschikt is, en dat geldt lang niet overal, maar als we dat vergelijken met het Franse doel van $4 \%$, dan is duidelijk dat hij een topprestatie levert in het kader van het terugdringen van $\mathrm{CO}_{2}$ in de atmosfeer. In Nederland is het terugdringen van $\mathrm{CO}_{2}$ in de afgelopen jaren gekoppeld aan ondergrondse opslag in aardlagen die daarvoor geschikt zijn. Maatschappelijk bleek dat niet aanvaardbaar. Maar als de overheid en de industrie kennelijk bereid zijn om geld te steken in verlaging van het $\mathrm{CO}_{2}$-gehalte van de atmosfeer, dan zou het voor de hand liggen om de agrarische wereld te steunen bij het verhogen van het organische stofgehalte van de bodem en dit onderdeel te maken van het gemeenschappelijk landbouwbeleid van de EU.

Het belang van het op peil houden van het organische stofgehalte van de bodem is ook enorm in de biobased economy. Daarmee wordt een economie aangeduid die zoveel mogelijk uitgaat van groene grondstoffen: producten die niet alleen worden voortgebracht voor voedsel, veevoer en vezels, maar ook voor brandstoffen, geurstoffen, smaakstoffen en dergelijke. Hoe meer producten we willen halen uit wat het land opbrengt, des te belangrijker is het om het productievermogen van de bodem in stand te houden. Anders mist de biobased economy de boot van de circular economy. Op dit punt heeft de bodemwetenschap nog een missie te vervullen. Om te beginnen in het overbrengen van die boodschap. Kijk maar eens naar het plaatje (figuur 4) van het voedselsysteem uit een recent rapport van de Wetenschappelijke Raad voor het Regeringsbeleid (43). 


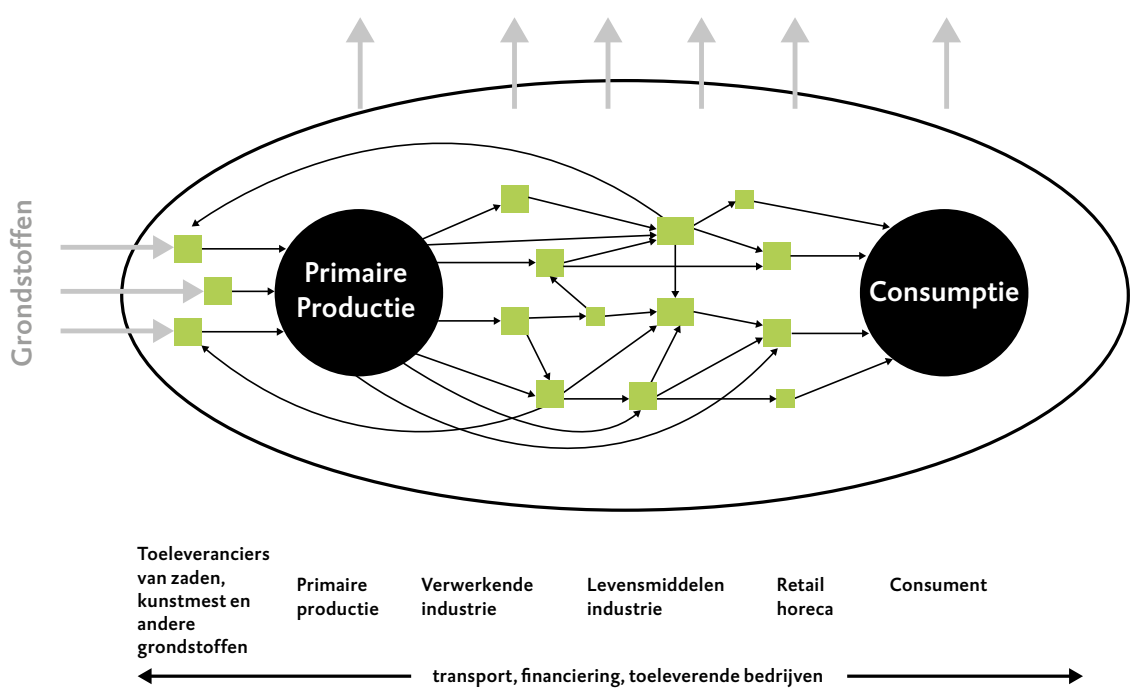

Figuur 4. Interactienetwerk van de hoofdrolspelers in de voedselketen. Merk op dat de verbinding tussen afval- en restromen enerzijds en grondstoffen anderzijds ontbreekt. Bron: WRR (43).

Dit plaatje beoogt alle spelers in de voedselketen en hun interacties in beeld te brengen, maar daar gaat het mij nu even niet om. Wat er niet klopt aan dit plaatje is dit: er gaan grondstoffen in en restproducten uit; het is dus een open systeem, géén circulair systeem. De omslag in denken naar werkelijk circulair gaat niet vanzelf. Een van de uitgangspunten in de biobased economy is het zoveel mogelijk 'verwaarden' van restproducten (43). Betekent dat dat de waardeloze resten teruggaan naar de bodem? Voor een werkelijk circulaire economie is het essentieel dat de hoeveelheid én kwaliteit van organische resten die teruggaan naar de bodem niet alleen bepaald worden door de wensen in de keten daaraan voorafgaand, maar óók, en misschien wel in de eerste plaats, door de hoeveelheid en kwaliteit die nodig is voor het duurzaam functioneren van de bodem. Ik onderschrijf dan ook van harte het pleidooi (28) om behoud van bodemvruchtbaarheid op te nemen als toetsingscriterium in de biobased economy. Pas dan zullen de reststoffen van gisteren de grondstoffen van vandaag leveren en de producten van morgen.

Gezien de klimaatopgave en de noodzaak van een circular biobased economy is de vraag van de akkerbouwers in de Hoeksche Waard naar het aanpassen van het 
bodemorganische stofbeheer dan ook meer dan een lokale, technische vraag: het is een algemene, welhaast existentiële vraag, want

\section{organische stof is niets minder dan de bodem onder ons aller bestaan.}

\section{Ons bodembiologisch onderzoek}

Graag wil ik $\mathrm{u}$ iets vertellen over het onderzoek dat de leerstoelgroep doet op het gebied van organische stof. Een deel van dat onderzoek richt zich op de meest actieve component, namelijk de opgeloste organische stof. Deze bevat op zijn beurt verschillende componenten, waarvan sommige gemakkelijker worden afgebroken dan andere (35). In het onderzoek naar organische stof werken we nauw samen met de leerstoelgroep Bodemscheikunde en Chemische Bodemkwaliteit van collega Rob Comans. Ellis Hoffland, staflid in onze leerstoelgroep, vormt hierin een belangrijke brugfunctie.

Aan het andere uiterste van het spectrum van afbreekbaarheid van organische stof vinden we houtskool. Houtskool wordt in tal van bodems aangetroffen. Sommige bodems zijn er zelfs naar genoemd: terra preta do indio= zwarte aarde, gevormd onder invloed van het landgebruik door de inheemse bevolking van het Amazonegebied. Die zwarte aarde vormt eilanden van vruchtbaarheid in een niet-vruchtbare omgeving. Omdat in zwarte aarde houtskool wordt aangetroffen, wordt het vaak in één adem genoemd met biochar, een soort houtskool dat wordt gefabriceerd door organisch materiaal onder hoge temperaturen te verhitten zonder zuurstof. Het ligt dan ook voor de hand om ons af te vragen of we met biochar het organische stofgehalte van de bodem en tegelijk de vruchtbaarheid kunnen verhogen.

We hebben gevonden dat toevoeging van biochar aan grond zelfs de afbraak van de al aanwezige bodemorganische stof vermindert ten opzichte van grond zonder biochar (25). We willen graag weten op welk mechanisme dit berust, want het verschijnsel treedt niet onder alle omstandigheden op. Genoeg vragen dus, waaraan de naam van staflid Thom Kuyper is verbonden.

Tussen opgeloste organische stof en houtskool zit een breed spectrum van organische resten die aan de bodem kunnen worden toegevoegd van al dan niet vergiste mest tot (wormen)compost. Interessant in dit verband is het onderzoek naar het zogenaamde home field advantage, letterlijk het thuisvoordeel. Het blijkt dat mest het best wordt afgebroken als deze wordt toegediend op de boerderij waar de mest ook is geproduceerd (33). Het ondergrondse deel van het ecosysteem is dus aangepast aan wat als voedsel beschikbaar komt uit het bovengrondse deel van het ecosysteem en het kan voedsel van elders niet net zo makkelijk verwerken. Aan dit werk heeft staflid Ron de Goede een belangrijke bijdrage geleverd. Van hem wil ik graag nog iets vertellen. Vorig jaar heeft hij zich bijzonder ingespannen voor de zogenaamde 
bodemdierendag, een initiatief van het Centrum voor Bodemecologie, het virtuele samenwerkingsverband van alle groepen die er in Nederland toe doen op het gebied van de bodemecologie. Ik licht dat even uit, omdat dit initiatief deze week (de week van dierendag -4 oktober) is uitgebreid tot een tiendaags gebeuren, waarin iedereen die dat wil, waarnemingen aan bodemdieren kan doorgeven (www.bodemdierendagen.nl). Een soort natuurkalender voor de bodem dus. Terug naar de wetenschap. Zoals u merkt, houdt de vraag hoe we meer organische stof in de bodem kunnen opslaan ons sterk bezig. Zo blijken bepaalde mengteelten daar bijzonder geschikt voor te zijn. Hoe meer plantensoorten bij elkaar groeien, des te meer koolstof wordt er in de bodem opgeslagen. Interessant genoeg gaat dat ook samen met meer bovengrondse productie (21). Het onderzoek naar plantbodeminteracties is het terrein van staflid Gerlinde De Deyn.

Natuurlijk zoeken we naar win-win situaties waarbij het vastleggen van bodemorganische stof zowel de landbouwkundige productie als andere zogenaamde ecosysteemdiensten bevordert. Maar dat lukt niet altijd. Zo is gebleken dat regenwormen weliswaar in het algemeen de plantaardige productie verhogen, maar ook de productie van broeikasgassen, waaronder het zeer krachtige lachgas (31). Hier moeten we dus zoeken naar een balans waarbij het ene bevorderd en het andere zo min mogelijk gestimuleerd wordt (39). Dit is het terrein van staflid Jan Willem van Groenigen.

We vinden de regenwormen weer aan de goede kant als het gaat om het verminderen van de risico's van klimaatverandering. Het weer laat steeds meer hoge pieken in de regenval zien, wat in het begin van het groeiseizoen de bovengrondse productie negatief kan beïnvloeden. Maar als er regenwormen zijn, zijn er ook gangen en daardoor wordt het water sneller afgevoerd. Ze maken bovendien extra gangen bij hevige regenval. Als gevolg daarvan is gebleken dat regenwormen de nadelen van hevige regenval op de groei van planten kunnen compenseren (1). Het gewas is dus veel minder kwetsbaar als er regenwormen zijn. Bij dit type onderzoek speelt staflid Mirjam Pulleman een belangrijke rol. Zij draagt ook ons deel van het onderzoek in de Hoeksche Waard.

Hoewel de voorbeelden die ik heb gegeven duidelijk laten zien dat er een nauwe samenhang is tussen gewasresten, bodemorganismen, bodemorganische stof en chemische en fysische processen in de bodem, is ook duidelijk dat de relaties kwantitatief sterk afhankelijk zijn van het type organische stof en de biotische en abiotische omstandigheden in de bodem. Om die reden is het te simpel gedacht dat er algemeen geldende 1:1 relaties zouden kunnen zijn tussen de componenten in dit schema of tussen bodemorganische stof en plantaardige productie of andere ecosysteemdiensten. Daarvoor moeten we differentiëren naar verschillende combinaties van bodemtype, klimaat en landgebruik en dat doen we dan ook in ons onderzoek. 
Dan nog een enkel woord over mijn eigen onderzoek. Zo'n 30-35 jaar geleden heb ik gewerkt aan mijn proefschrift over mestkevers, die gangen graven en daar mest in brengen als voedsel voor de larven. Fascinerend, fundamenteel onderzoek. Over dat onderzoek is na mijn promotie in 1985 een paginagroot artikel verschenen in De Telegraaf, voor één dag mijn favoriete krant. Het leuke is nu dat dat bijna 30 jaar later, in 2014, nog een keer gebeurd is, deze keer in De Volkskrant, ook voor één dag mijn favoriete krant. Ik laat met veel plezier de omslag zien van het boekje dat Caspar Janssen (26), de VK-journalist, heeft gepubliceerd, vol met werkelijk fantastische portretten van mensen die letterlijk gebiologeerd zijn door hun studieobject. Wat heb ik verder in die 30 jaar aan onderzoek gedaan? Ik voel me ongemakkelijk bij het onder woorden brengen van mijn eigen verdiensten. Laten we het er maar op houden dat ieder staflid van de leerstoelgroep een belangrijk aandeel heeft gehad in het oordeel van een officiële externe commissie die in 2015 de kwaliteit en relevantie van ons onderzoek heeft bestempeld als excellent.

Een collega heeft me eens eclectisch genoemd. Dat betekent "geen enkel systeem volgend, maar selecterend en gebruikend wat kan worden beschouwd als de beste elementen van alle systemen". Dat klopt wel. Ik beschouw mezelf als een generalist. In de biologie is alles interessant en dat is ook wel gebleken uit het brede assortiment aan proefschriften dat mede onder mijn leiding tot stand is gekomen. Ik had er plezier in om initiatieven te nemen voor nieuwe cursussen en veelbelovend onderzoek en ook het regelmatig schrijven van wetenschappelijke overzichtsartikelen en meningsvormende stukken heb ik altijd belangrijk gevonden (2-14, 16-20, 24, 29-30, 32, 36-37, 39-41).

In weerwil van alle variatie is er samenhang in wat wij doen. Ons adagium is 'leren van de natuur', als doel op zich, maar zeker ook om de verworven kennis te kunnen toepassen. Dat hoeft niet van vandaag op morgen. De universiteit is er juist voor lange termijnonderzoek. En intussen zijn we bereid om onze kennis te delen met iedereen. Dat is ook wat we onze studenten willen laten ervaren. Derde- en ouderejaarsstudenten brengen in mei een week in de Hoeksche Waard door voor een veldpracticum. We doen dit nu al bijna 10 jaar en het is voor de studenten steeds weer geweldig om mee te maken hoe enthousiast ze worden ontvangen door boeren, natuurbeschermers, waterschappen en overheden. Nergens anders in het onderwijs werk je als studenten zo nauw samen met inspirerende voorbeelden: docenten én praktijkmensen. De waarde van veldpractica voor het leerproces van studenten kan niet worden overschat.

Van ons onderzoek heb ik in het bestek van deze rede maar weinig kunnen vertellen en in die zin doe ik onvoldoende recht aan de overige thema's waaraan mijn leerstoelgroep werkt (kringlopen van plantenvoedende stoffen, bodem(organisme)plant interacties, microbiële interacties, bodembiodiversiteit, bodemstructuur en 
porositeit e.d.). Wat wij doen, doen we bovendien niet alleen. We werken met twee buitengewoon hoogleraren die ons aanvullen waar onze kennis beperkt is en met vier postdocs. En we hebben een klein leger aan promovendi, vaak mede-begeleid door groepen elders waarmee we nauw samenwerken. Jaarlijks staat een aantal van hen hier in de aula om hun proefschrift te verdedigen. En allemaal worden we ondersteund door mensen voor wie geen moeite te veel is om ons het werken mogelijk te maken.

I leave this group with great confidence to my successor Rachel Creamer. Rachel, you inherit a group of eminent scientists, with great support staff and working in a friendly and productive atmosphere. There is a saying that it is easier to reach the top than to stay there. So, I'd better leave. But I am not sure the saying is right. These people are up to the challenge of staying at the top and I am sure that your expertise and leadership will be instrumental in that respect.

Ik heb geen tijd om het uit te spinnen, maar ieder van de stafleden van mijn leerstoelgroep ontleent haar of zijn waarde niet alleen aan onderwijs en onderzoek, maar ook aan wat we doen om Wageningen University \& Research vooruit te helpen binnen haar doelstellingen. We zijn actief in het genderbeleid, het onderwijsinstituut, de onderzoekschool Production Ecology \& Resource Conservation, de ondernemingsraad, Wageningen Young Academy, populair-wetenschappelijke publicaties, allerlei voorlichtingsactiviteiten, zoals de filmpjes die u vandaag ziet en optredens in de media van het Jeugdjournaal en Vroege Vogels tot De Kennis van $\mathrm{Nu}$. Maar wat ons toch het meest motiveert, is 20 jaar geleden in een schitterend essay van de hoogleraar sociale filosofie De Valk onder woorden gebracht als ‘De twaalf vreugden van de wetenschap' (23). Daarvan noem ik er hier vier:

De eerste hebben betrekking op onderzoeken:

- de verwondering, de bron van alle kennis;

- de ontdekking van nieuwe kennis of de oplossing van een probleem;

- het inzicht, het begrijpen van samenhang in de werkelijkheid.

De laatste heeft betrekking op onderwijzen:

- het uitleggen van gewonnen inzichten aan anderen, dat is niet de simpele overdracht van kennis, maar het leren begrijpen.

In feite gaat het om passie, want

\section{de wil om te begrijpen is de bodem onder ons bestaan als wetenschapper.}

Laat $\mathrm{u}$ dat even bezinken bij het kijken naar de volgende filmpjes, die medewerkers van mijn leerstoelgroep met behulp van een professionele fotograaf hebben gemaakt. Voor $\mathrm{u}$ links ziet $\mathrm{u}$ een groeiende plantewortel, rechts ziet $\mathrm{u}$ het in de bodem 
verdwijnen van vers organisch materiaal. De groeiende wortel staat voor de compositie van biomassa uit water, plantenvoedende stoffen en $\mathrm{CO}_{2^{\prime}}$ aangevuurd door het zonlicht bovengronds. Voor $\mathrm{u}$ rechts ziet $\mathrm{u}$ het verdwijnen van organisch materiaal, in beeld gebracht door de regenwormen. Dit staat voor de decompositie van wat biomassa wás tot de eerder samenstellende delen van water, plantenvoedende stoffen en $\mathrm{CO}_{2}$ onder afgifte aan het bodemleven van de energie die de zon erin gestoken had. Tussen opgaan en verzinken, hier niet in beeld gebracht maar $\mathrm{u}$ welbekend, ligt de fase van het blinken, de fase van vruchtbaarheid waarin de plant de delen voortbrengt die wij oogsten en als voedsel tot ons nemen. Om uit verzinken weer tot blinken te kunnen overgaan geven we terug van wat we genomen hebben tot instandhouding van de bodemvruchtbaarheid. Dit ziende, realiseert $\mathrm{u}$ zich dat mijn vakgebied, de bodembiologie, een metafoor is voor het leven zelf, voor opgaan, blinken, verzinken en weer opgaan in een oneindige kringloop.

\section{De waarde(n) van de wetenschap}

Na zoveel jaar onderzoek, onderwijs en bestuurlijke activiteiten ligt het voor de hand dat er, als ik terugkijk, gedachten opkomen over wat nu eigenlijk wezenlijk is in de wetenschapsbeoefening. Daaraan wil ik graag het laatste gedeelte van mijn rede wijden.

Ik laat $u$ een plaatje zien van drie personen: een hoogleraar, een geestelijke en een rechter. Zij lijken op elkaar doordat zij alle drie een toga dragen. Daarmee drukken zij uit dat zij niet namens zichzelf spreken, maar bepaalde waarden vertegenwoordigen. We zien hier hoogwaardigheidsbekleders. De hoogleraar vertegenwoordigt de waarheid, de geestelijke de waarachtigheid en de rechter de gerechtigheid. Eigenlijk moet ik zeggen: zij vertegenwoordigen niet de waarheid, de waarachtigheid en de gerechtigheid, maar waarheid, waarachtigheid en gerechtigheid, zonder 'de' ervoor. Er is namelijk niet één waarheid, één waarachtigheid of één gerechtigheid. Het is nóg beter om te stellen dat we hier vertegenwoordigers zien van het zoeken naar waarheid, zoeken naar waarachtigheid en zoeken naar gerechtigheid. Kenmerkend voor dat zoeken is de twijfel: de hoogleraar vraagt zich af of de evidentie voor het verschijnsel dat hij bestudeert overtuigend is, de geestelijke vraagt zich af of zij de geschriften en overleveringen waarop zij zich baseert goed doorgrondt en de rechter vraagt zich af of hij de wet en het gevoelen in de samenleving goed tot uitdrukking brengt in zijn oordeel. Voor alle drie is dus de twijfel de basis voor hun uitspraken, niet de zekerheid. In het zoeken naar gerechtigheid is de twijfel zelfs geïnstitutionaliseerd, doordat de rechter te maken heeft met een aanklager en een advocaat. In het zoeken naar waarheid is de twijfel ook geïnstitutionaliseerd doordat in een aula als deze iedere promovendus zijn proefschrift moet verdedigen tegen de bezwaren van een commissie van hoogleraren voordat hem het getuigschrift wordt overhandigd dat hij in staat is tot het zelfstandig beoefenen van de wetenschap. De paranimfen die hem 
daarbij terzijde staan, hadden oorspronkelijk zelfs de functie om hem fysiek te beschermen tegen degenen die hun bezwaren letterlijk kracht wilden bijzetten. Het belang van twijfel in de wetenschap komt echter vaak niet over het voetlicht. Als u op de televisie een wetenschapper ziet, dan is de aanleiding daarvoor vaak een ontdekking of een nieuwe toepassing van kennis. Kortom, de wetenschapper wordt voorgesteld als iemand die iets te weten is gekomen, dat voor $\mathrm{u}$ belangrijk is. Wat daardoor verborgen blijft, is dit: de wetenschapsbeoefening in de werkelijkheid van alledag is een voortdurend zoeken naar wat we nog níet weten. Het is meer dan tasten in het duister, want er is altijd wel een spoor. Maar heel vaak loopt dat dood. Als je eenmaal iets hebt dat je de moeite van het publiceren waard vindt, dan wordt je manuscript anoniem beoordeeld door collega-wetenschappers en die wijzen het vaak af. Als je eenmaal iets hebt kunnen publiceren, is je doel voorlopig bereikt, maar je werk houdt slechts stand tot anderen hebben aangetoond dat je ongelijk had of met iets komen dat als een verbetering wordt gezien. Voortdurend wordt er dus door jezelf en door anderen getwijfeld aan het resultaat van onderzoek. We noemen dat organized skepticism. Zo werkt de wetenschap.

Officiële uitspraken van de rechter, geestelijke of hoogleraar worden in het openbaar gedaan en mogen, omdat twijfel aan de basis ervan staat, altijd aangevochten worden. Nou ja, altijd? Nee, er zijn landen waar de rechter zich niet onafhankelijk kan uitspreken. Dat kan leiden tot klassejustitie en onderdrukking die aanleiding kunnen zijn tot verzet en in het ergste geval tot revolutie. Er zijn religies die geen twijfel dulden en dat kan leiden tot afscheidingen en in het ergste geval tot vervolging van ketters en ongelovigen. Ik laat het terrein van gerechtigheid en waarachtigheid verder rusten, want vandaag gaat het over de wetenschap, maar ik noteer wel dat ook de wetenschap niet kan bestaan zonder de erkenning van waarden, anders zou er geen Nederlandse Gedragscode Wetenschapsbeoefening (42) hoeven zijn, die als kernwaarden benoemt: eerlijkheid \& zorgvuldigheid, betrouwbaarheid, controleerbaarheid, onpartijdigheid en onafhankelijkheid. Deze zijn mede zo belangrijk omdat ze ons laten nadenken over hoe we onze studenten leren zich tot de kernwaarden te verhouden als wezenlijk voor de wetenschapsbeoefening. Dat is temeer noodzakelijk omdat veel van onze studenten afkomstig zijn uit een cultuur waaraan de notie van een wetenschap die onafhankelijk is van religie en politiek wezensvreemd is. Vaak is dat ook een cultuur waarin een onafhankelijke opstelling in de sociale verbanden van familie, godsdienst en politiek evenzeer ongebruikelijk is. Een voorbeeld hiervan is de opschudding die ontstond toen een Leidse promovendus in 2014 Allah dank zegde in zijn proefschrift. Hetzelfde overkwam trouwens een Wageningse promovendus, alleen toen ging het om dankzegging aan God. Dat werd aanvankelijk categorisch verboden. Vervolgens werd dat ijlings weer teruggedraaid, officieel omdat het dankwoord geen deel uitmaakt van de examenstof die een proefschrift is. 
Dit voorbeeld van wat ik een existentiële worsteling zou willen noemen, laat zien hoe belangrijk het is dat in de loop van het studieprogramma rede en waarden bij elkaar gebracht en gehouden worden. Het instrument daarvoor is aanwezig, namelijk de filosofie. In de filosofie speelt de rede een grote rol, maar gaat het ook over waarden. Wageningen doet het in die zin prima dat het een ruim aanbod heeft aan filosofieonderwijs. In veel gevallen zit de filosofie echter in de bachelorfase en dat lijkt mij een te vroeg stadium van ontwikkeling van de student. Als we dit onderwijs opnemen in de masterfase, bereiken we bovendien de talrijke buitenlanders die in deze fase instromen, afkomstig uit culturen waarin kritische reflectie en onafhankelijkheid in de wetenschap niet vanzelfsprekend zijn. En helaas zit filosofie lang niet in alle studieprogramma's. Juist de cursus Wetenschapsfilosofie zit in geen enkel studieprogramma als verplicht element. Een groot deel van het aanbod aan filosofische vakken komt dus alleen ten goede aan de studenten die er in hun vrije ruimte zelf voor kiezen en dat zijn er niet veel. Dit lijkt mij stof tot nadenken voor de opleidingscommissies want

\section{voor studenten is de wetenschapsfilosofie de bodem onder hun bestaan.}

Hoe krijgen we dat over het voetlicht? Terwijl de kernwaarden van de wetenschap in de loop der jaren dezelfde zijn gebleven, is de aandacht ervoor verminderd door de enorm toegenomen prestatiedruk. We moeten, zonder dat er veel meer werktijd voor beschikbaar gesteld wordt, veel meer doen dan in mijn beginjaren en dat geldt zowel voor studenten als voor universitaire medewerkers. $\mathrm{Nu}$ is dat in de meeste sectoren zo, ook in het publieke domein, denk maar aan de zorgsector. Maar toch. De wetenschap publiceert als geheel en per onderzoeker steeds meer artikelen. De studentenaantallen zijn de afgelopen jaren flink toegenomen en dat merk je als docent heel goed. En we steken steeds meer energie en tijd in het uitdragen van ons onderzoek en andere vormen van wisselwerking met de samenleving. Dat is belangrijk en we doen het graag, maar werkweken van meer dan 60 uur zijn heel gewoon en dan bedoel ik niet bij uitzondering, maar voortdurend. Niet goed voor het sociale leven. De vraag is gerechtvaardigd: kan het ook anders? En inderdaad, er zijn mogelijkheden. Het onderwijs is sterk aan het veranderen. We experimenteren met flipped classrooms en thesis rings, waarin studenten elkaar stimuleren in het leerproces en elkaars werk beoordelen. Dit zijn slechts twee voorbeelden van nieuwe vormen die én het leerproces beogen te versnellen én de docent minder tijd kosten per student. Maar de vraag hoe we voldoende aandacht, en dus tijd, kunnen schenken aan de vorming, de Bildung, wordt er alleen maar urgenter door. Bij toenemende studentenaantallen gaan we die tijd niet vinden met efficiënter onderwijs. Minder tijd besteden aan onderzoek dan? Het begint langzamerhand door te dringen dat almaar meer publiceren uiteindelijk niemand ten goede komt. In de woorden van een zeer 
recent artikel in Nature (34): "Het pad waarop we ons nu bewegen dreigt de wetenschap te verzuipen in de ruis van haar eigen toenemende productiviteit... Dit lot te vermijden vereist onder meer veel selectiever publiceren.... We kunnen beginnen met minder en minder vaak te publiceren". Hiermee ben ik het van harte eens, maar dat kan niet afhankelijk zijn van individuele keuzen. Dit moet beleid worden. Het wordt echt tijd dat de bestuurders van de universiteiten hun menselijk kapitaal beschermen en achter mensen als Rik Torfs, rector van de Katholieke Universiteit Leuven gaan staan, die in dagblad De Morgen van 21 september 2015 aankondigde dat zijn universiteit enkel nog naar de vijf beste publicaties kijkt in plaats van naar de totale hoeveelheid. Torfs zegt hierover: "We beseffen dat we op eigen kracht de internationale publicatiecultuur niet kunnen omdraaien, maar we kunnen wel met kleinere, gerichte maatregelen voor verandering zorgen". Als wat hij hier zegt op grote schaal werkelijkheid wordt, zal dat tot grote opluchting leiden bij mensen die wel getalenteerd zijn voor de wetenschap, maar niet bereid of in de positie zijn om zich er totaal aan over te geven.

Dames en heren, ik heb u meegenomen op een tocht die begon met 'wetenschap in context' met als voorbeeld ons onderwijs en onderzoek in de Hoeksche Waard. Ik heb vervolgens geschetst wat ons in onze leerstoelgroep inspireert en ik ben geëindigd bij de (wetenschaps)filosofie. Het belang van de confrontatie en combinatie van algemeen aanvaarde kernwaarden van de wetenschap en de eigen waarden van de wetenschapsbeoefenaar komt in Wageningen tot uiting in aparte leerstoelen voor humanistische, reformatorische en katholieke wijsbegeerte. Moeten we nu, gezien de samenstelling van de studentenpopulatie er een op islamitische grondslag aan toevoegen? Maar waar is dan het einde? Wellicht verdient het de voorkeur om in het filosofie-onderwijs aandacht te geven aan de overeenkomsten en verschillen in waarden tussen álle grote levensbeschouwingen. Het zou de universiteit ten voorbeeld stellen aan alle instituties die de integratie van mensen met verschillende wereldbeelden en afkomstig uit verschillende culturen serieus willen nemen. Dit thema is van groot belang, want in de woorden van Klaas van Egmond (38), schrijver van het weergaloze boek 'Een vorm van beschaving', zit de discussie tussen wetenschap en religie nog steeds muurvast, terwijl slechts een integrale cultuur, waarin idealistische en materialistische waarden met elkaar worden verenigd, zou leiden tot een samenleving "waarin geen tegenstellingen meer zouden bestaan tussen wetenschap, religie, filosofie, ethiek en kunst". Wacht even: kunst? Inderdaad, ik zie dat ideaal mooi verbeeld in het kunstwerk van herman de vries (figuur 5) dat door bemiddeling van collega Nico van Breemen en met steun van tal van collega's is aangeschaft door de Raad van Bestuur en dat $\mathrm{u}$ op onze campus kunt bewonderen: veritas existentiae. 


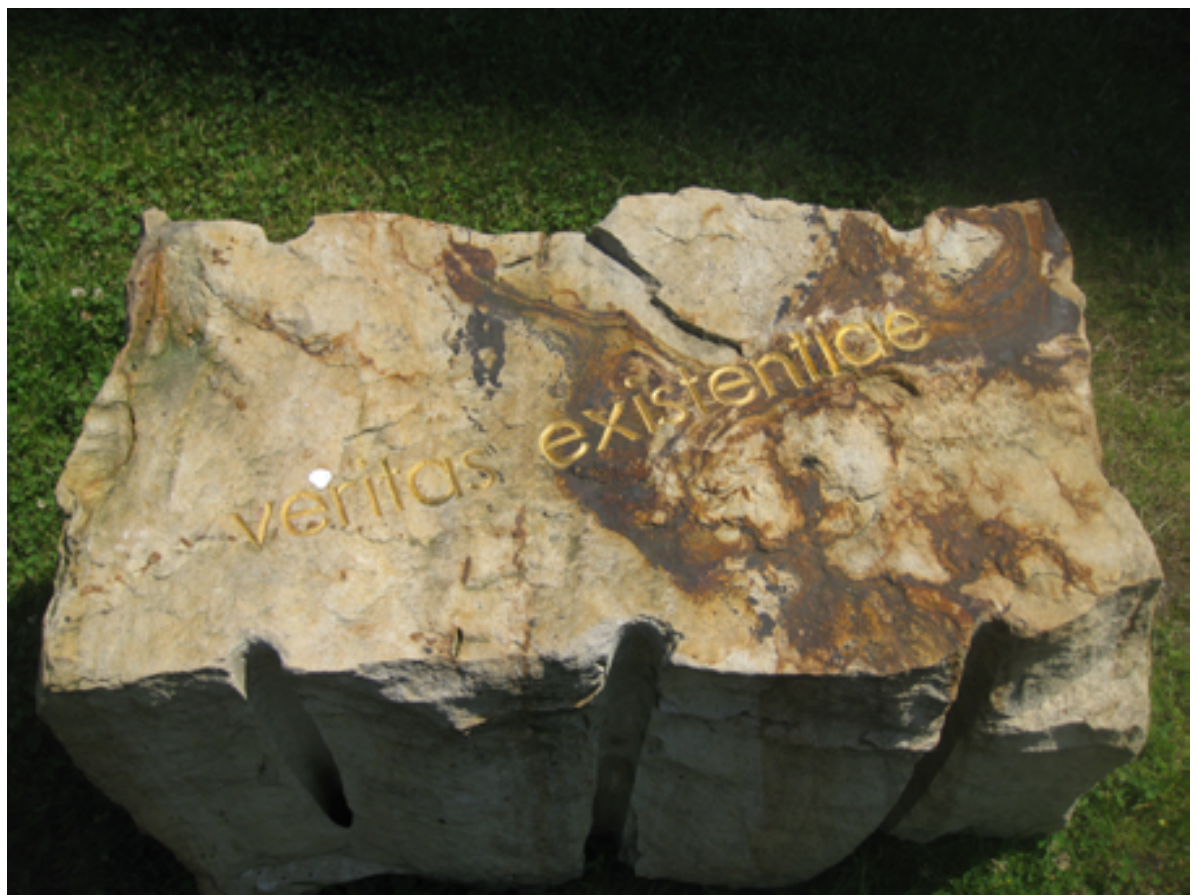

Figuur 5 . Het beeld 'veritas existentiae' van herman de vries op de campus van Wageningen University $\mathcal{E}$ Research.

Veritas, dat is waarheid, dat is waarnaar wij als wetenschappers zoeken. Veritas existentiae is wel vertaald als 'waarheid van het bestaan', maar 'existentiële waarheid' raakt mijns inziens de kern beter, omdat de term 'existentiële' de bodem onder ons bestaan verwoordt die ik $\mathrm{u}$ in verschillende gedaanten uiteengezet heb, namelijk:

- de organische stof: in materiële zin de bodem onder ons aller bestaan

- de wil om te begrijpen: de bodem onder ons bestaan als wetenschappers en de voedingsbodem voor 'Bildung' in ons onderwijs, en

- de filosofie, in het bijzonder de wetenschapsfilosofie: de bodem onder het bestaan van onze studenten.

In deze trits herkent $\mathrm{u}$ zowel de materiële, fysische als de immateriële, metafysische bodems onder ons bestaan en de wisselwerking daartussen als essentiële ingrediënten in onze zoektocht naar waarheid, naar veritas existentiae. 
Het is een hoge roeping om eraan bij te dragen dat ieder op deze planeet in materiële zin is voorzien in de basis onder ons bestaan, want zonder dat is geen leven mogelijk. Maar daarnaast is de immateriële basis van zoveel mogelijk gedeelde waarden evenzeer van belang, want zonder dat is geen samenleven mogelijk. De westerse wetenschap moet zich haar eigen waarden herinneren, dat wil zeggen opnieuw verinnerlijken als urgente gespreksbasis met studenten uit westerse landen, maar zeker ook met studenten uit andere culturen. Zij gaan vaak verantwoordelijke posities innemen in hun land van herkomst en kunnen daarmee een verbindende factor zijn in een verdeelde wereld.

Aan het einde van mijn rede gekomen, wil ik graag enkele dankwoorden uitspreken. Dat ik deel heb uitgemaakt van een gemeenschap van mensen met dezelfde passie voor de zoektocht naar waarheid, was gewoon fantastisch. Ik heb een beroepsleven lang mogen werken met de meest getalenteerde mensen die de samenleving voortbrengt. Ik ben dus in de eerste plaats de samenleving dankbaar, die haar nazaten toevertrouwt aan de universiteit in een ontvankelijke fase van hun leven. Ik hoop dat mijn rede zal worden opgevat als een verantwoording naar de samenleving en voor het geval dat niet helemaal gelukt is, heb ik nog iets voor $\mathrm{u}$ in petto: $\mathrm{u}$ krijgt bij het verlaten van de aula het boekje Leve(n)de bodem! uitgereikt (15). Dit boekje bevat essays en interviews over mijn vakgebied, uitgegeven door de Stichting Biowetenschappen \& Maatschappij.

De leerstoel bodembiologie is in 1988 ingesteld door de toenmalige rector Prof. Henk van der Plas en de toenmalige decaan Prof. Louis Schoonhoven. Ik ben hen en de achtereenvolgende bestuurders van deze universiteit, vandaag gepersonifieerd door de rector magnificus, dankbaar dat ze de leerstoel, die ik als eerste heb mogen bekleden, de mogelijkheid hebben gegeven zich in de 28 jaar die achter mij ligt te ontwikkelen tot wat die nu is. Ik heb zelf enkele malen verantwoordelijkheid genomen als bestuurder, dus ik weet dat hun taak niet gemakkelijk is. Ik heb oprechte bewondering voor diegenen onder de bestuurders die begrijpen wat een wetenschapper beweegt en er hun beroepseer in stellen daarvoor zoveel mogelijk bewegingsruimte te bieden.

Ook mijn leerstoelgroep ben ik bijzonder dankbaar. Jullie zijn een fantastisch team, dat zinvol onderzoek doet en inspirerend onderwijs geeft en dat wordt ondersteund door beheerspersoneel voor wie geen moeite te veel is. Nu behoor ik natuurlijk te zeggen dat het leiding geven aan jullie een voorrecht was. En het wás ook een voorrecht. Tegelijk was het, eerlijk waar, een makkie. Mijn stelregel is altijd geweest: als je doet wat je moet doen en je doet het goed, dan stel ik verder geen vragen. Ik heb hoogstens nu en dan wat moeten bijsturen, maar in feite zijn we een zelfsturende groep, waarin ik me niet meer heb gevoeld dan primus inter pares. 
Wie ik het meest dankbaar ben, zit op de voorste rij, ook letterlijk op de eerste plaats. Cineke, zolang wij elkaars leven delen, en dat is al heel lang, heb je meer voor mij betekend dan wie ook, met een kritische geest, milde spot en grote loyaliteit, kortom met ware liefde. Jíj bent de bodem onder míjn bestaan.

Meneer de rector, dames en heren, ik dank u voor uw aandacht.

Ik heb gezegd. 


\section{Literatuur}

1. Andriuzzi WS, Pulleman MM, Schmidt O, Faber JH, Brussaard L (2015). Anecic earthworms (Lumbricus terrestris) alliviate negative effects of extreme rainfall events on soil and plants in field mesocosms. Plant and Soil 397: 103-113.

2. Blanchart E, Albrecht A, Alegre J, Duboisset A, Villenave C, Pashanasi B, Lavelle P, Brussaard L (1999). Effects of earthworms on soil structure and physical processes. In: Earthworm management in tropical agroecosystems / Lavelle P, Brussaard L, Hendrix P (eds.). Oxon, UK: CABI Publishing.

3. Blouin, M, Hodson ME, Delgado EA, Baker G, Brussaard L, Butt KR, Dai J, Dendooven L, Peres G, Tondoh JE, Cluzeau D, Brun, JJ (2013). A review of earthworm impact on soil function and ecosystem services. European Journal of Soil Science 64: 161-182.

4. Brown GG, Edwards CA, Brussaard L. (2004). How earthworms affect plant growth: burrowing into the mechanisms. In: Earthworm ecology / Edwards CA, CRC Press, Boca Raton, 13-49.

5. Brown GG, Swift MJ, Bennack DE, Montánez A, Brussaard L (2007). Management of soil biodiversity in agricultural systems. In: Managing biodiversity in agricultural ecosystems / Jarvis DI, Padoch C, Cooper HD (eds), Columbia University Press, 224 - 268.

6. Brussaard L (1994). An appraisal of the Dutch Programme on Soil ecology of arable farming systems. Agriculture, Ecosystems and Environment 51: 1-6.

7. Brussaard L (1994). The ecology of soil organisms in sustainable farming systems. In: Soil biota management in sustainable farming systems / Pankhurst CE, Doube BM, Gupta VVSR, Grace PR (eds). CSIRO, Australia, 197-203.

8. Brussaard L (1998). Soil fauna, functional groups and ecosystem processes. Applied Soil Ecology 9: 123-135.

9. Brussaard L (2012). Ecosystems services provided by the soil biota. In: Soil Ecology and Ecosystems Services / Wall DH, Bardgett RD, Behan-Pelletier V, Herrick JE, Jones TH, Ritz K, Six J, Strong DR, van der Putten WH (eds). Oxford University Press, UK, 54-64. 
10. Brussaard L, Aanen, DK, Briones MJI, Decaëns T, De Deyn GB, Fayle TM, James SW, Nobre T (2012). Biogeography and phylogenetic community structure of soil invertebrate ecosystem engineers - global to local patterns, implications for ecosystem functioning and services and global environmental change impacts. In: Soil Ecology and Ecosystems Services / Wall DH, Bardgett RD, BehanPelletier V, Herrick JE, Jones TH, Ritz K, Six J, Strong DR, van der Putten WH (eds). Oxford University Press, UK, 201-232.

11. Brussaard L, Behan-Pelletier VM, Bignell DE, Brown VK, Didden WAM, Folgarait PJ, Fragoso C, Freckman DW, Gupta VVSR, Hattori T (1997). Biodiversity and ecosystem functioning in soil. Ambio 26: 563-570.

12. Brussaard L, Caron P, Campbell B, Lipper L, Mainka S Rabbinge R, Didier D, Pulleman MM (2010). Reconciling biodiversity conservation and food security: scientific challenges for a new agriculture. Current Opinion in Environmental Sustainability 2: 34-42.

13. Brussaard L, de Ruiter PC, Brown GG (2007). Soil biodiversity for agricultural sustainability. Agriculture, Ecosystems and Environment 121: 233-244.

14. Brussaard L, Ferrera-Cerrato R. (eds) (1997). Soil Ecology in Sustainbale Agricultural Systems. CRC Press/Lewis Publishers, Boca Raton, 168 pp.

15. Brussaard L, Govers FPM, Buiter, R. (red.) (2016). Leve(n)de bodem! Cahiers Biowetenschappen en Maatschappij 2016-3 (http://www.biomaatschappij.nl/ product/levende-bodem/), 88 pp.

16. Brussaard L, Hauser S, Tian G, 1993. Soil faunal activity in relation to the sustainability of agricultural systems in the humid tropics. In: Soil organic matter dynamics and sustainability of tropical agriculture / Mulongoy K, Merckx R (eds). Wiley/Sayce, Chichester etc., 241-256.

17. Brussaard L, Juma NG (1996). Organisms and humus in soils. In: Humic substances in terrestrial ecosystems / Piccolo A (ed). Elsevier, Amsterdam, 329-359.

18. Brussaard L, Kooistra MJ (eds), 1993. Soil structure - soil biota interrelationships. Geoderma (Special issue) 56: 1-648 and 57: 1-181.

19. Brussaard L, Kuyper TW, Didden WAM, de Goede RGM, Bloem J (2004). 
Biological soil quality from biomass to biodiversity - importance and resilience to management stress and disturbance. In: Managing soil quality - challenges in modern agriculture / Schjønning P, Elmholt S, Christensen BT (eds), CABI, Wallingford, UK, 139-161.

20. Brussaard L, Pulleman MM, Ouédraogo E, Mando A, Six J (2007). Soil fauna and soil function in the fabric of the food web. Pedobiologia 50: 447-462.

21. Cong W, van Ruijven J, Mommer L, De Deyn GB, Berendse F, Hoffland E (2014). Plant species richness promotes soil carbon and nitrogen stocks in grasslands without legumes. Journal of Ecology 102: 1163-1170.

22. Conijn JG, Lesschen JP (2015). Soil organic matter in the Netherlands quantification of stocks and flows in the top soil. PRI report 619 / Alterra report 2663, Wageningen University \& Research, 68 pp.

23. De Valk JMM (1996). De twaalf vreugden van de wetenschap. Socialisme \& Democratie 53: 67-76.

24. Filser J, Faber JH, Tiunov AV, Brussaard L, Frouz J, De Deyn GB, Uvarov AV, Berg MP, Lavelle P, Loreau M, Wall DH, Querner P, Eijsackers H, Jimenez JJ (2016). Soil fauna: key to new carbon models. Soil 2: 565-582.

25. Francischinelli Rittl T, Novotny EH, Baliero FC, Hoffland E, Alves BJR, Kuyper TW (2015). Negative priming of native soil organic carbon mineralization by oilseed biochars of contrasting quality. European Journal of Soil Science 66: 714-721.

26. Janssen C (2015). In de ban van het beest = Nederlandse dieren door de ogen van hun kenners. Atlas contact, Amsterdam, $224 \mathrm{pp}$.

27. Keesstra SD, Bouma J, Wallinga J, Tittonell P, Smith P, Cerdà A, Montanarella L, Quinton JN, Pachepsky Y, van der Putten WH, Bardgett RD, Moolenaar S, Mol G, Jansen B, Fresco LO (2016). The significance of soils and soil science towards realization of the United Nations Sustainable Development Goals. Soil 2: $111-128$.

28. Klijn N (2012). De biobased economy en duurzaam bodemgebruik. Biorenewables Business Platform, Key Insight Solutions, Den Haag, 46 pp. 
29. Lavelle P, Brussaard L, Hendrix P (eds), 1999. Earthworm management in tropical agroecosystems. CABI Publishing, Oxon, UK, 300 pp.

30. Lebbink G, van Faassen HG, van Ouwerkerk C, Brussaard L (1994). The Dutch programme on soil ecology of arable farming systems: farm management, monitoring programme and general results. Agriculture, Ecosystems and Environment 51: 7-20.

31. Lubbers IM, van Groenigen KJ, Fonte SJ, Six J, Brussaard L, van Groenigen JW (2013). Greenhouse-gas emissions from soils increased by earthworms. Nature Climate Change 3: 187-194.

32. Pascual U, Termansen M, Hedlund K, Brussaard L, Faber JH, Foudi S, Lemanceau P, Liv-Jørgensen S (2015). On the value of soil biodiversity and ecosystem services. Ecosystem Services 15: 11-18.

33. Rashid MI, de Goede RGM, Brussaard L, Lantinga EA (2013). Home field advantage of cattle manure decomposition affects the apparent nitrogen recovery in production grasslands. Soil Biology and Biochemistry 57: 320-326.

34. Sarewitz (2016). The pressure to publish pushes down quality. Nature 533: 147.

35. Straathof AL, Chincarini R, Comans RNJ, Hoffland E (2014). Dynamics of soil dissolved organic carbon pools reveal both hydrophobic and hydrophilic compounds sustain microbial respiration. Soil Biology and Biochemistry 79: 109-116.

36. Struik PC, Kuyper TW, Brussaard L, Leeuwis C (2014). Deconstructing and unpacking scientific controversies in intensification and sustainability: why the tensions in concepts and values? Current Opinion in Environmental Sustainability 8: 8o-88.

37. Tian G, Brussaard L, Kang BT, Swift MJ (1997). Soil fauna-mediated decomposition of plant residues under constrained environmental conditions. In: Driven by Nature - Plant Litter Quality and Decomposition / Cadish G, Giller KE (eds). CABI, Wallingford, 125-134.

38. Van Egmond K (2010). Een vorm van beschaving. Christofoor, Zeist, 294 pp.

39. Van Groenigen JW, Velthof GL, Oenema O, van Groenigen KJ van Kessel C 
(2010). Towards an agronomic assessment of $\mathrm{N}_{2} \mathrm{O}$ emissions: a case study for arable crops. European Journal of Soil Science 61: 903-913.

40. Van Noordwijk M, Brussaard L (2014). Minimizing the ecological footprint of food: closing yield and efficiency gaps simultaneously? Current Opinion in Environmental Sustainability 8: 62-70.

41. Verhoef HA, Brussaard L (1990). Decomposition and nitrogen mineralization in natural and agro-ecosystems: the contribution of soil animals. Biogeochemistry 11: 175-211.

42. VSNU (2014). De Nederlandse gedragscode wetenschapsbeoefening - principes van goed wetenschappelijk onderwijs en onderzoek. Vereniging van Samenwerkende Nederlandse Universiteiten. Den Haag, 11 pp.

43. WRR (2014). Naar een voedselbeleid. Wetenschappelijke Raad voor het Regeringsbeleid, Rapport 93. Amsterdam University Press, Den Haag/ Amsterdam, $173 \mathrm{pp}$. 



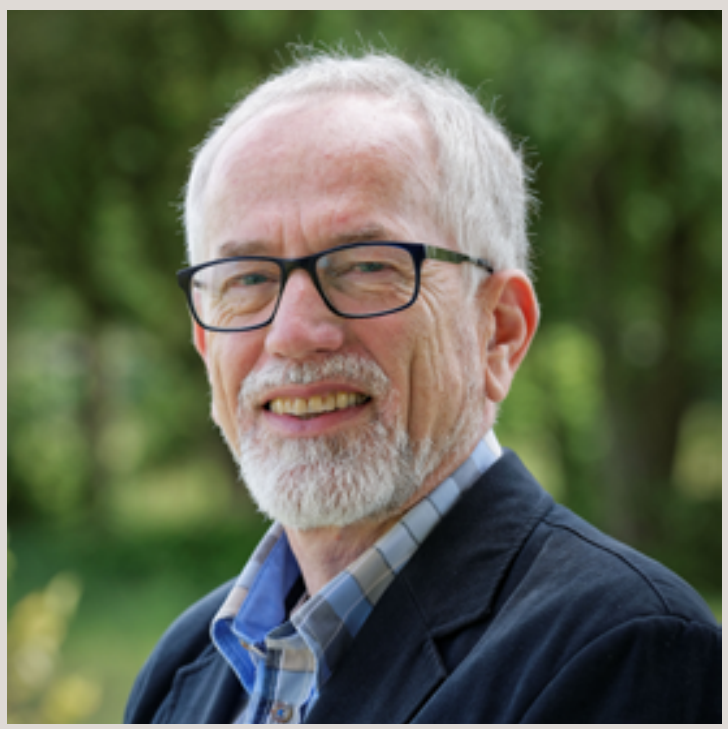

Prof.dr. Lijbert Brussaard

'Organische stof in de bodem is een zeer belangrijke productiefactor voor ons voedsel.

Verhoging van het organische stofgehalte van de bodem gaat samen met de opslag van koolstof; de bodem speelt daarmee ook een hoofdrol in het tegengaan van de opwarming van het klimaat.

In de circulaire biobased economy neemt de bodem de organische resten van gisteren op als de grondstoffen van vandaag en verandert die in de producten van morgen.

Organische stof is dus de bodem onder ons bestaan.' 